\title{
WORKING CAPITAL MANAGEMENT IN DELL INC
}

\author{
Kolar Nada ${ }^{1}$
}

\begin{abstract}
The topic of this research is the relationship between working capital management and company performance complemented with detailed review of cash flow management of Dell Inc. In the last century, in literature on operational finance management, the focus is on methods used to improve operational efficiency and decrease the cash conversion cycle. Cash flow is widely explored in corporate finance litetature, and it is usually related to company profitability, yet not a lot of resaerch analyzes the role of supply chain management. The academic purpose of this study is to describe the elements of working capital management and company performance relationship from a supply chain management perspective.
\end{abstract}

Key words: working capital management / inventory turnover / supply chain / cash conversion cycle

\section{INTRODUCTION}

The main financial goal of companies is the maximization of value and working capital management is employed to support that main purpose. Companies need cash to start business and maintain operations. Working capital is defined as difference between of short term assets and short term liabilities. Working capital management, as the name itself says, is dedicated to the analysis of quantity and elements of working capital in order to sustain company's short term liabilities, which are short term debt and operational expenses.

In order to measure performance of working capital management companies use the metric named cash conversion cycle. This metric essentially shows the period of time from paying for raw materials to collecting the payments from customers and it is formed out of three elements: accounts receivable, inventory days and accounts payable. Cash conversion cycle shows the average number of days that working capital is required in operational cycle.

\footnotetext{
${ }^{1}$ Faculty of Economics and Engineering Management, University Business Academy in Novi Sad, nada.kolar@gmail.com
} 
As main topic in operational finance management literature of the last century, we come across the question on how to improve operational efficiency and decrease the cash conversion cycle. Improvement can be achieved through shortening production cycle from raw materials to finished goods (cycle time improvement), decreasing waste in production process (quality management of input and output components) and decrease in physical inventory owned by company which can be managed through cooperation with customers and vendors. Several paths are suggested in order to achieve this goal, including the reengineering of business processes, total quality management, supply chain integration, just-in-time approach and agile production. Inherent logic of these techniques is evident and widely accepted, and studies from operational management field show increase in market participation, higher profitability and improved quality of product within companies that use them. Existing studies show negative correlation between cash conversion cycle and profitability ${ }^{2}$ therefore many companies are trying to decrease their cash conversion cycle.

\section{METHODOLOGY}

\section{Research topic}

The topic of this research is the relationship between working capital management and company performance with detailed review of cash flow management of Dell Inc.

\section{Research purpose}

Cash flow is widely explored in corporate finance literature, and is usually related to company profitability, yet not a lot of research deals with the role of supply chain management. The academic purpose of this study is to describe relationship elements of working capital management and company performance from a supply chain management perspective.

\section{Research methodology and techniques}

Taking into consideration the subject that will be explored and purpose of this research, deductive approach will be used. Research includes two fields of study-

${ }^{2}$ Hutchinson P.D., Farris II T.M., and Anders S.B.- Cash-to-Cash Analysis and Management. Useful Performance Measures for Improving Profitability 
working capital management and supply chain management. Further in this paper we will deal with cash conversion cycle and processes relevant to supply chain management. In order to achieve the general research purpose and analyze research topic, the case study method will be used to determine how company with negative cash conversion cycle relates to processes of demand, supply and inventory management.

This research is based on the information collected from different sources of domestic and foreign literature, including books, technical and scientific studies and papers. Empirical study and document analysis was conducted within Dell Mexico. Additionally, non-academic papers and corporate documents were used in order to better understand company business practices. Financial data was taken from annual financial reports, i.e. Form $10-\mathrm{K}$ which Dell submits to US Securities and Exchange Commission. The last report was submitted on Feb 1st 2013 for fiscal year 2013. In November 2013, Dell has become a privately held company and financial results are not readily available any more.

\section{General hypothesis}

- Efficient working capital management improves company performance.

\section{Specific hypotheses}

- Accounts receivable are in negative correlation with company profitability.

- Accounts payable are in negative correlation with company profitability.

- Inventory levels are in negative correlation with company profitability.

- Cash conversion cycle is in negative correlation with company profitability.

\section{WORKING CAPITAL MANAGEMENT}

\section{Working Capital Definition}

The amount by which the firm's current assets exceed its current liabilities constitutes its working capital, or net working capital, as it is referred to as:

Working Capital $=$ Current Assets - Current Liabilities 
There are various metrics to measure working capital performance. Some of the most frequently used are: liquidity ratio, quick ratio, inventory turns, receivables turns, days of payables outstanding, etc. All of these metrics reveal different aspects of working capital positions. ${ }^{3}$

\section{Cash Conversion Cycle}

There are several definitions of cash conversion cycle.

Cash conversion cycle on a monthly basis represents the difference between total expected cash income in determined month on one side, and total value of expected spending on the other side. Brealey defines it as the length of time between the firm's payment for its raw materials and the collection of payment from the customer. $^{4}$ The following definition is slightly different: cash conversion cycle is a number of days that a firm's operational cycle requires financing for. ${ }^{5}$

Cash conversion cycle consists of three elements: DOI (days of inventory), DRO (days of receivables outstanding), DPO (days of payables outstanding).

$$
\mathrm{CCC}=\mathrm{DOI}+\mathrm{DRO}-\mathrm{DPO}
$$

DOI is the length of the average time frame that elapses from the purchase of materials from suppliers to the sale of corresponding items to customers. As this metric is added up in the calculation of CCC, it may be assumed that the lower it is, the better it is for the firm. Cutting inventory will bring a lower DOI; but too low a DOI may mean that the firm is compromising its service levels.

Days of Inventory $(D O I)=365 /$ Yearly Inventory Turnover = Average Inventory / (COGS/365)

DRO is calculated by dividing the number of days in a year by yearly accounts receivable turnover. Therefore, DRO relates directly to accounts receivable turnover. Accounts receivable turnover is calculated by dividing net sales by average accounts receivable in a given time frame. It shows the number of times customers are invoiced and the payments received from them are recorded on the income statement during the time frame in question. In other words, DRO is the average number of days that elapse from the issuance of bill to a customer up to the collection of the corresponding cash from that customer.

\footnotetext{
3 Sagner J. - Essentials of Working Capital Management, 2010, p. 7

${ }^{4}$ Brealey R.A., Myers S.C., Marcus A.J. - Fundamentals of Corporate Finance, 2012, p. 534

${ }^{5}$ Sagner J. - Essentials of Working Capital Management, 2010, p. 16
} 
Days Receivable Outstanding $(D R O)=365 /$ Yearly Accounts Receivable Turnover $=$ Average Accounts Receivable / (Net Sales/365)

DPO is calculated by dividing the number of days in a year by yearly accounts payable turnover. For that reason, it has a direct connection to accounts payable turnover, which is calculated by dividing the cost of goods sold by average accounts payable in a given time frame. It measures the number of times a full cycle of being billed by suppliers and making the corresponding payments to those suppliers is completed in a given time frame.

Days Payable Outstanding $(D P O)=365 /$ Yearly Accounts Payable Turnover $=$ Average Accounts Payable / (COGS/65)

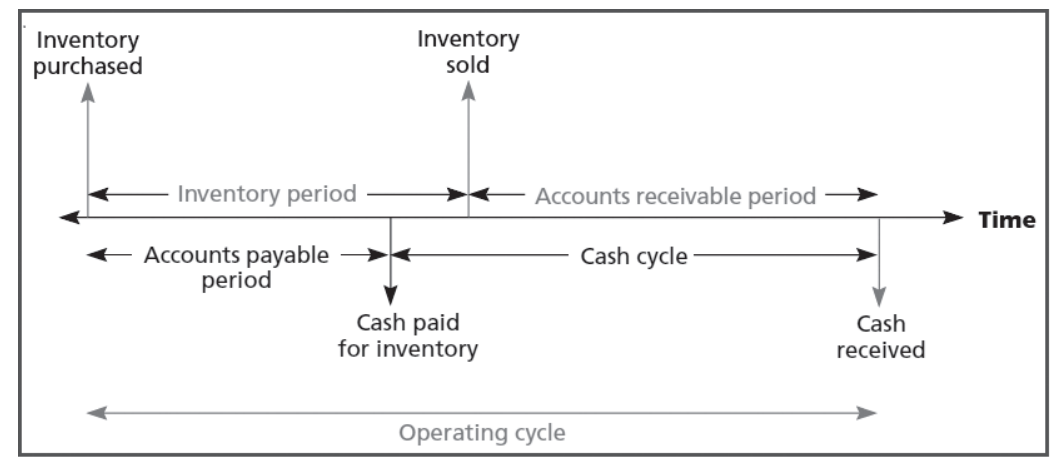

Image 1: Relationship between CCC and profitability ${ }^{6}$

In his research Deloof points out the negative correlation between cash conversion cycle and gross revenue, reaffirming statements of earlier authors that were researching this topic in American companies. Some authors disapprove of this connection in manufacturing and services companies, but acclaim continuous improvement in cash flows essential for maintaining of competitive advantage. ${ }^{7}$

This improvement can be achieved in several ways.

a) Reduce DRO by:

1. Following up quickly on delinquent accounts.

2. Assessing interest on delinquent accounts.

3. Requiring cash on delivery payments for future orders from delinquent customers.

${ }^{6}$ Jordan, R. W. - Fundamentals of Corporate Finance, 2003, p. 643

${ }^{7}$ Deloof M. - Does Working Capital Management Affect Profitability of Belgian Firms? Journal of Business Finance \& Accounting, April 2003, p. 573-588 
4. Allowing for automatic deposit of payments.

b) Shorten production cycle to reduce DOI by:

1. Reducing bad overage inventory, through adopting strategies such as justin-time delivery, real time inventory tracking, collaborative planning forecasting and replenishment.

2. Synchronizing supply/demand planning.

3. Cross-docking of material at warehouse locations.

c) Increase average DPO by:

1. Paying at the last possible minute or date.

2. Making partial rather than full payments to vendors.

3. Reducing frequency of payment.

4. Utilizing interest-free credit cards

\section{SUPPLY CHAIN MANAGEMENT}

\section{Supply Chain definition}

The importance of supply chain for financial flows is expressed in the following statement- supply chain is a set of three or more companies directly linked by one or more of the upstream and downstream flows of product/services, finances, and information from a source to a customer.

\section{JIT (Just-In-Time)}

The most common method used in inventory management is JIT (just-in-time). The first company to use it was Toyota which led to inventory and cycle time reduction and on the other hand improved the financial results. JIT concept is defined as the inventory management strategy dedicated to the improvement of company business and financial results by elimination of overstock and associated costs. In order to apply the JIT system, company needs to maintain stable and long-term relationships with vendors, since the new product needs to be delivered as soon as stock reaches its minimum (Veselinović, Vunjak, 2014, str. 185). Therefore, timely communication is crucial in the production process and it implies communication with manufacturers on one side and transport companies on other side. This 
kind of information is available through modern IT infrastructure- internet and ERP (Enterprise Resource Planning). ERP is a corporate information system used for integration of production process with accounting figures and other functions within organization. The main purpose of ERP is to provide data to all functional segments and instant access to the information that supports decision making process. Internet and ERP considerably improve the JIT inventory management system, allowing the tracking and sharing of production and accounting information in real time. By the end of the 1990s, JIT and ERP concepts have become integrated in a concept known as Supply Chain Management, defined as running the network of interconnected functional units. ${ }^{8}$

To this date, the relationship between inventory management and financial performance hasn't been fully explored. Several authors write about negative correlation in retail where the value is found in timely availability of product, as opposed to manufacturing where the value is mainly found in value added services, product innovation and efficient fulfillment. ${ }^{9}$

\section{Inventory turnover}

Inventory turns indicates the number of times per year the companies such as retailers and manufacturers are able to sell off or use up their complete inventory of raw materials or finished goods. ${ }^{10}$ To maximize sales with the least amount of inventory, the company should try to meet demands by ordering smaller quantities more frequently from the suppliers, which leads to achieving more inventory turns, which refer to the annual number of times that average inventory sells.

The inventory turns can be expressed mathematically as:

Inventory turns $=$ Sales volume at cost/Value of average inventory

Increasing inventory turns means the company is holding fewer inventories on average, while at the same time being able to fulfill customer demand. The company's finance desires to reduce inventory, increase inventory turnover, and yield high capital return on assets. But the company should note that there is no such conclusion that the more inventory turns, the better the inventory policy. Again, individual company should recognize an appropriate number in their best interest. Graph

\footnotetext{
${ }^{8}$ Kannan V.R, Keah Choon Tan - Just in time, Total quality management, and Supply Chain Management. Understanding their linkages and impact on business performance

${ }^{9}$ Gleissner H., Femerling J.C. - Logistics, 2013, p. 26

${ }^{10}$ Roseman A., How To Optimize Inventory Turnover Rates. Keep Cash In The Bank And Reduce Missed Sales Opportunities With This Formula.
} 
1 gives an example to demonstrate the relationship between inventory carrying cost and inventory turns. As inventory turns increase, inventory carrying cost will reduce.

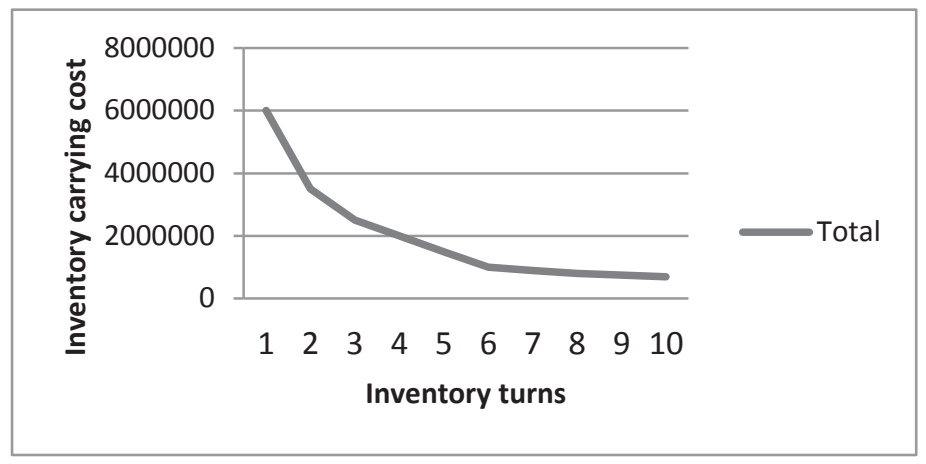

Graph 1. Inventory carrying costs and inventory turns

\section{Inventory tradeoffs}

As to the performance measurement of a supply chain there are various parameters that should be taken into consideration from different perspectives. However, some of them are tradeoffs, which mean that there are conflicting goals in SCM. There are 3 three most common tradeoffs concerning inventory: (a) The product variety-inventory tradeoff; (b) The lot size-inventory tradeoff; (c) The transportation cost-inventory tradeoff.

\section{WORKING CAPITAL MANAGEMENT IN DELL INC.}

\section{Company information}

Dell is one of the leading technology companies, offering a broad range of products, including desktop PCs, servers, networking products, storage, mobility products, software and peripherals, and services. Dell is headquartered in Round Rock, Texas, and employs about 109,400 people $^{11}$

The company is organized in three geographic lines: Americas, Asia-Pacific and Japan, and Europe/Middle-East/Africa (EMEA). Each of the region has its own regional headquarter and its own assembly plants and supply network. Regional headquarters include Bracknell (UK) for EMEA, Singapore for Asia-Pacific and

${ }^{11}$ Form 10-K FY 2013 http://www.dell.com/learn/us/en/uscorp1/about-dell-investor 
Kawasaki for Japan. In terms of sales, the Americas account for $72 \%$ of Dell's revenues, EMEA for $20 \%$ of sales and Asia-Pacific equals $8 \%$ of sales.

Dell operations are organized around four business segments:

1. Enterprise solutions: servers, networking and storage products

2. Enterprise services: infrastructure technology, consulting and applications, and product-related support services

3. Software and peripherals: printers, PCs accessories, networking and wireless products, digital cameras, and other products

4. Client products: mobility and desktop PC products.

As demonstrated in Table 1, client products represent the core business of the company with $\$ 28,294$ million revenues in FY13, consisting in the $50 \%$ of total company's revenues. ${ }^{12}$

FY13

FY12

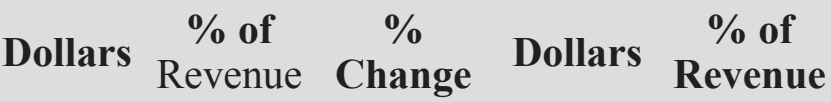

Net revenue

Enterprise solutions and

services:

Enterprise solutions

\begin{tabular}{llllll}
\hline Servers and networking & 9,294 & $16 \%$ & $11 \%$ & 8,336 & $13 \%$ \\
\hline
\end{tabular}

\begin{tabular}{lccccc}
\hline Storage & 1,699 & $3 \%$ & $-13 \%$ & 1,943 & $3 \%$ \\
\hline Services & 8,396 & $15 \%$ & $1 \%$ & 8,322 & $13 \%$ \\
\hline
\end{tabular}

Third-party software and peripherals

$9,257 \quad 16 \% \quad-9 \% \quad 10,222 \quad 17 \%$

\begin{tabular}{lccccc}
\hline Client & & & & & \\
\hline Mobility & 15,303 & $27 \%$ & $-20 \%$ & 19,104 & $31 \%$ \\
\hline Desktop PCs & 12,991 & $23 \%$ & $-8 \%$ & 14,144 & $23 \%$ \\
\hline Total net revenue & $\mathbf{\$ 5 6 , 9 4 0}$ & $\mathbf{1 0 0 \%}$ & $\mathbf{- 8 \%}$ & $\mathbf{\$ 6 2 , 0 7 1}$ & $\mathbf{1 0 0 \%}$ \\
\hline
\end{tabular}

Table 1: Dell revenue for FY12 and FY13 13

12 Form 10-K FY 2013 http://www.dell.com/learn/us/en/uscorp1/about-dell-investor

${ }^{13}$ Form 10-K FY 2013 http://www.dell.com/learn/us/en/uscorp1/about-dell-investor 
Dell has created a unique model within its industry: it pioneered the build-to-order computer business at a time when no one thought that the average customer would have been willing to wait for the arrival of a computer that he or she had not even seen. Now people are logging onto the company website, designing their own computers, and anxiously awaiting arrival. They can track the pace of their ordered computer through the manufacturing process and distribution channel, to the point where customers know what stage of the manufacturing process their customized computer is in at any point on a given day. This level of transparency allowed Dell to sell one out of three computers in the US.

\section{Working Capital Management}

Since 1986, Dell was focused on growth, however market limitations of direct model have quickly came to surface. In order to surpass limits of direct sales through build to order moved, Dell decided to distribute part of its products through PC supermarkets and other retailers like Wal-Mart and Best Buy.

In 1994, quality issues appeared and company needed to provide more cash in order to support growth and maintain leading PC industry position. Dell was in serious problems with cash flow and in fiscal year ending in Jan 1994, sales reached $\$ 2.8 \mathrm{~B}$, but the balance was concerning, company reported $\$ 36 \mathrm{M} \mathrm{loss.}^{14}$

In order to mitigate this situation, Dell applied JIT inventory management approach and the results were promising- there was drastic inventory days reduction. Instead of tying up cash in excess inventory, Dell could use the released cash flow to support further growth. As a result, Dell reached strong cash flow and high profitability which is shown in its financial reports.

During 1993, Dell had very strong growth with high inventory and cash conversion cycle was increasing. As mentioned before, strong growth led to deficit of cash and Dell suffered its first loss in 1994. One of previous Dell's CFO Thomas Meredith noticed that if company is only focused to growth it leads to destabilizing of profitability and liquidity. ${ }^{15}$ Therefore, the conclusion is that the cash conversion cycle is the key metric to balance the goals of growth, profitability and liquidity.

\footnotetext{
${ }^{14}$ Annual reports, 1996 Fiscal Year in Review http://www.dell.com/learn/us/en/uscorp1/aboutdell-investor

15 Barr S. CFO Magazine 1998. Performance Measurement \& Risk management At Dell Computer Corp., speed and balance are the secret weapons to creating value.
} 
By the end of 1994, Dell's cash conversion cycle was 41 days. As a result of improved inventory management, component prices and quality, Dell had a positive balance in 1995 and cash conversion cycle decreased to 35 days.

Dell's success is also a result of a very simple idea- eliminate the middleman. This approach enabled Dell to remove the retailer margin and avoid high costs of inventory. Dell could deliver product to the customer directly at lower costs and on top of that provide outstanding service and customer support. After the cash flow was adopted as new performance metric, Dell improved direct sales strategy and build-to-order approach. The growth continued and liquidity was included as strategy priority.

Dell's direct model improves the cash flow performance for three main reasons:

1. Dell maintains very low inventory levels of finished goods that are sold to the customer.

2. Dell maintains very low inventory levels of components and WIP, since parts are procured on JIT basis.

3. Cash conversion cycle remains favorable, since customers often pay to Dell, before Dell pays its vendors. ${ }^{16}$

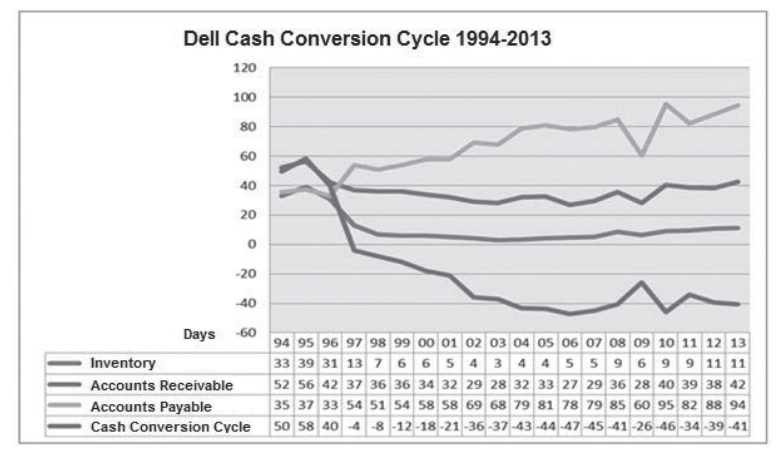

Graph 2: Dell cash conversion cycle 1994-2013

Between 2002 and 2008, the average cash conversion cycle was 42 days. One of the factors that influence the decrease of number of days is inventory reduction, which is a direct consequence of Dell's improved inventory management.

Directionally, Dell managed to significantly decrease the number of days of cash conversion cycle from 1993 to 2013. Since 2006, Dell's cash conversion cycle is increasing.

${ }^{16}$ Fisher, L.M. Inside Dell Computer Corporation: Managing Working Capital. 1998. 


\begin{tabular}{|l|c|c|c|c|c|c|c|c|}
\hline Year & 2013 & 2012 & 2011 & 2010 & 2009 & 2008 & 2007 & 2006 \\
\hline CCC & -40.67 & -39.46 & -34.26 & -46.06 & -25.91 & -40.51 & -45.06 & -47.09 \\
\hline
\end{tabular}

Table 2. Dell Cash conversion cycle 2006 - 2013

The trend of increasing in CCC may be a result of one of following causes:

1. Less rigorous build-to-order model.

2. Vendors take over the major part of finished goods assembling.

3. A larger part of sales and fulfillment goes through retailers and distributors.

The conclusion is that Dell has shown the success of direct model growing from a local company at the beginning of the 1980s to a leading global IT company. Considering that direct model eliminates retailer margins, Dell managed to provide higher value to its customers. This model produces all-inclusive customer relationship development, strong customer service and support; build to order approach, maintaining low inventory levels and quick response to market changes. Dell employs direct model to improve service and customer support, keeping its leading position.

\section{Supply Chain}

When it comes to supply chain management in the computer industry, Dell Computer sets the standard. The company converted its operations to a build-to-order process, eliminated its inventories through a just-in-time system, and sold its products directly to consumers.

Dell is adopting a networking approach for dealing with its supply chain. Dell in fact does not own a manufacturing plant for computer components, but it only handles the key final assembly and configuration processes, with a network of suppliers and contract manufacturers supporting each assembly plant. This is possible thanks to the high commitment of all the players that are involved in Dell's value chain, which as shown below comprehend: component suppliers and contract manufacturers, Dell assembly plants, third-party logistics providers and final customers. 


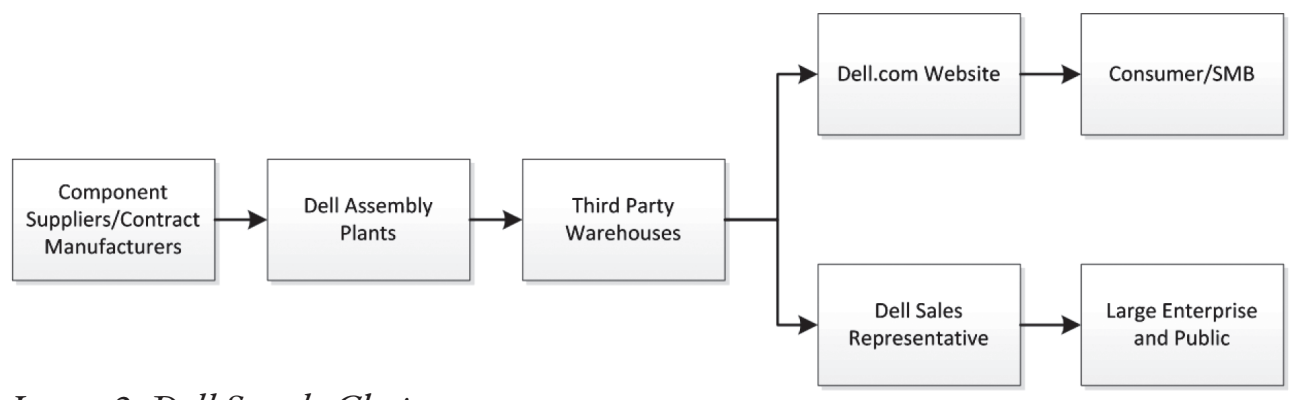

Image 2. Dell Supply Chain

Michael Dell, founder and CEO of Dell, refers to the supply chain strategy of the company as to virtual integration, meaning that the effective use of technology enables coordination across company boundaries to achieve new levels of efficiency and productivity, as well as extraordinary returns to investors. As a consequence, the virtual integration offers the advantages of a tightly coordinated supply chain that have traditionally come through vertical integration. At the same time, it benefits from the focus and specialization that drive virtual corporations. Thus, Michael Dell envisions virtual integration as having the potential to achieve both coordination and focus.

The strategies adopted by Dell for achieving the virtual integration with the different partners in the supply chain are presented further.

\section{Component suppliers and contract manufacturers}

In order to effectively achieve the virtual integration strategy goal of Michael Dell, the company focuses on stimulating tight supplier relationships so that suppliers can focus on parts innovation while Dell can focus on customers and on the management of the supply chain. The rule followed by Dell is to have as few partners as possible but that will last as long as they maintain their leadership in technology and quality. For assuring this, Dell keeps what it calls a supplier report card on every supplier, and tracks each supplier's performance against a set of metrics maintained by Dell. Vendors are primarily evaluated based on four criteria: quality, cost, delivery and technology. As a result of the closed relationship with its suppliers, about 30 of them provide $75 \%$ of Dell's direct material purchase spent. However, in order to avoid shortage of components, Dell has two or more supply sources for each component, even for processors that are almost entirely bought from Intel Corporation, a small part is purchased from AMD. 
Dell's supply chain is extended worldwide and, as depicted by the picture below, they key facilities are mainly located in Asia, United States and Central America, Brazil and Europe.

The majority of sourcing is from low cost suppliers in Asia; however some sourcing is from local producers. Regarding the sourcing for the Americas region, the breakdown of manufacturers by region is $35 \%$ from Asia, 30\% from Mexico and $35 \%$ from Brazil. For major components, Dell looks for suppliers with global capabilities such as Intel, Flextronics, Hitachi, Microsoft Corporation, Toshiba and Seagate, while local suppliers in each region provide other parts. As for contract manufacturers, the major part is performed by Foxconn, Compal and Wistron.

In order to succeed in the implementation of its forward supply chain, Dell adopts two main supply chain strategies for managing its relationship with its suppliers: modularity and vendor managed inventory. Dell uses the technique of modularity for achieving a high degree of specialization for each component. Modularity involves the organization of complex products by decomposing them into smaller portions that can be managed independently. The standardized parts associated with modularization also allow for the components to be built by different suppliers. This let Dell have its supplier to focus on R\&D while Dell can focus on quickly utilizing the new technology due to the lack of inventory within its supply chain. Dell can therefore avoid investment into potentially unprofitable areas and capitalize on new technology developed by its suppliers and put into modular components that are easily integrated into a standard Dell box. Moreover, the modularity technique has allowed the firm to effectively implement the build-to-order strategy and to gain a competitive advantage through the mass customization of the final products.

\section{Inventory management}

In order to increase the flexibility of supply chain, Dell does not manage the inventory but has its suppliers ship components from their factories to hubs. Dell indirectly pays for this through the component pricing, but the company does not actually take possession of the inventory until the parts enter the Dell plant. In addition, the company helps its suppliers negotiate transportation costs and it arranges for dedicated shipping space which its supplier can use. Dell also determines the target inventory levels and records supplier deviations to determine incentives.

In order to reduce the inventory levels, Dell shares information regarding forecasts with its suppliers to ensure that the assembly plant receives the needed supplies in 
a timely manner. The major part of Dell's component purchases are now handled online: suppliers use an Internet portal to view Dell's requirements and changes to forecasts based on marketplace activity, and to confirm their ability to meet Dell's delivery requirements. Then, as Dell factories receive orders and schedule assemblies, a "pull" signal to the supplier triggers the shipment of the materials required to build current orders. Dell also confirms to its customers accurate delivery dates.

\section{Dell fulfillment centers}

Dell does not manufacture its own components or subassemblies but it handles the final assembly for nearly all of its PCs and servers. The company organizes manufacturing by region, operating a total of seven assembly plants to serve its major markets.

Manufacturing centers are located in- Americas operations: Hortolandia, Brazil and Ciudad Juarez, Mexico, EMEA operations: Lodz, Poland, APJ operations: Shanghai, China; Penang, Malaysia; Bangalore, India.

In order to decide where to open each plant, Dell bases its decision on five key factors: market access, labor cost and quality, transportation and telecommunications infrastructure, government incentives, and absence of industry clusters.

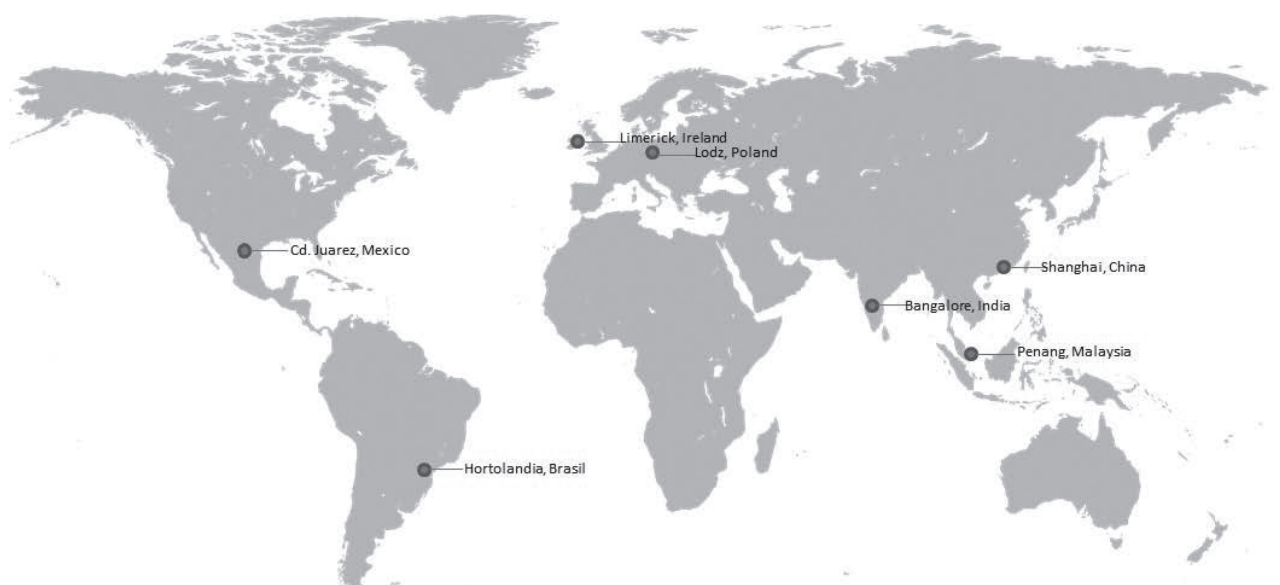

Image 3: Dell Manufacturingfacilities

\section{Cash Conversion Cycle analysis in Dell}

The table below shows the results of Pearson's correlations, which demonstrates that all factors related to cash conversion cycle (INV, AP and AR) are in negative 
correlation with companies profitability indexes- ROA and ROE, except for AP and ROE.

$\begin{array}{ccccccc} & \text { INV } & \text { AR } & \text { AP } & \text { CCC } & \text { ROA } & \text { ROE } \\ \text { INV } & 1 & * & * & * & * & * \\ \text { AR } & 0.8875 & 1 & * & * & * & * \\ \text { AP } & -0.6403 & -0.4138 & 1 & * & * & * \\ \text { CCC } & 0.9078 & 0.7655 & -0.894 & 1 & * & * \\ \text { ROA } & -0.4448 & -0.5063 & -0.1876 & -0.152 & 1 & * \\ \text { ROE } & -0.5704 & -0.6491 & 0.2191 & -0.47 & 0.6821 & 1\end{array}$

Table 3. Pearson's correlations for Dell financial indexes 1994- 2013.

The relevant information from Dell's financial reports from 1994 to 2013 used for this analysis is further exposed.

\begin{tabular}{|c|c|c|c|c|c|}
\hline Fiscal Year & 2013 & 2012 & 2011 & 2010 & 2009 \\
\hline Revenue & $\$ 56,940$ & $\$ 62,071$ & $\$ 61,494$ & $\$ 52,902$ & $\$ 61,101$ \\
\hline Cost of Revenue, Total & $\$ 44,754$ & $\$ 48,260$ & $\$ 50,098$ & $\$ 43,641$ & $\$ 50,144$ \\
\hline Net Income & $\$ 2,372$ & $\$ 3,492$ & $\$ 2,635$ & $\$ 1,433$ & $\$ 2,478$ \\
\hline Accounts Receivable-Trade, Net & $\$ 6,629$ & $\$ 6,476$ & $\$ 6,493$ & $\$ 5,837$ & $\$ 4,731$ \\
\hline Total Inventory & $\$ 1,382$ & $\$ 1,404$ & $\$ 1,301$ & $\$ 1,051$ & 867 \\
\hline Accounts Payable & $\$ 11,579$ & $\$ 11,656$ & $\$ 11,293$ & $\$ 11,373$ & $\$ 8,309$ \\
\hline Total Assets & $\$ 47,540$ & $\$ 44,533$ & $\$ 38,599$ & $\$ 33,652$ & $\$ 26,500$ \\
\hline Total Equity & $\$ 10,680$ & $\$ 8,917$ & $\$ 7,766$ & $\$ 5,641$ & $\$ 4,271$ \\
\hline Inventory Period & 11 & 11 & 9 & 9 & 6 \\
\hline AR Period & 42 & 38 & 39 & 40 & 28 \\
\hline AP Period & 94 & 88 & 82 & 95 & 60 \\
\hline Cash Conversion Cycle & -41 & -39 & -34 & -46 & -26 \\
\hline ROA & $5 \%$ & $8 \%$ & $7 \%$ & $4 \%$ & $9 \%$ \\
\hline ROE & $22 \%$ & $39 \%$ & $34 \%$ & $25 \%$ & $58 \%$ \\
\hline
\end{tabular}

Table 4. Fiscal Year 2009-2013. 
In millions, except ratios and percentages

Fiscal Year

\begin{tabular}{|c|c|c|c|}
\hline 2008 & 2007 & 2006 & 2005 \\
\hline$\$ 61,133$ & $\$ 57,420$ & $\$ 55,788$ & $\$ 49,205$ \\
\hline$\$ 49,462$ & $\$ 47,904$ & $\$ 45,897$ & $\$ 40,190$ \\
\hline$\$ 2,947$ & $\$ 2,583$ & $\$ 3,602$ & $\$ 3,043$ \\
\hline 136 & 131 & 126 & 110 \\
\hline 167 & 157 & 153 & 135 \\
\hline$\$ 5,961$ & $\$ 4,622$ & $\$ 4,082$ & $\$ 4,414$ \\
\hline$\$ 1,180$ & 660 & 588 & 459 \\
\hline$\$ 11,492$ & $\$ 10,430$ & $\$ 9,868$ & $\$ 8,895$ \\
\hline$\$ 27,561$ & $\$ 25,635$ & $\$ 23,252$ & $\$ 23,215$ \\
\hline 3,735 & $\$ 4,328$ & $\$ 4,129$ & $\$ 6,48$ \\
\hline
\end{tabular}

Inventory Period

AR Period

9
36

5

5

4

AP Period

Cash Conversion Cycle

85

29

27

33

$-41$

79

78

81

$-47$

$-44$

Table 5. Fiscal Year 2004-2008.

In millions, except ratios and percentages

Fiscal Year

Revenue

Cost of Revenue, Total

Net Income

Cost of revenue/ 365

Revenue/365

Accounts Receivable - Trade, Net

Total Inventory

Accounts Payable

Total Assets

Total Equity

Inventory Period

AR Period

AP Period

Cash Conversion Cycle

ROA

ROE

$\begin{array}{ccccc}2003 & \mathbf{2 0 0 2} & \mathbf{2 0 0 1} & \mathbf{2 0 0 0} & \mathbf{1 9 9 9} \\ \$ 35,404 & \$ 31,168 & \$ 31,888 & \$ 25,265 & \$ 18,243 \\ \$ 29,055 & \$ 25,661 & \$ 25,445 & \$ 20,047 & \$ 14,137 \\ \$ 2,122 & \$ 1,780 & \$ 2,310 & \$ 1,860 & \$ 1,460\end{array}$

Table 6. Fiscal Year 1999-2003. 
In millions, except ratios and percentages

Fiscal Year

Revenue

Cost of Revenue, Total

Net Income

Cost of revenue/ 365

Revenue/365

Accounts Receivable - Trade, Net

Total Inventory

Accounts Payable

Total Assets

Total Equity

Inventory Period

AR Period

AP Period

Cash Conversion Cycle

ROA

ROE

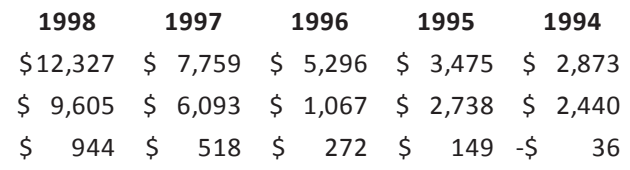

$\begin{array}{rrrrrrrrrr}\$ & 1,486 & \$ & 903 & \$ & 726 & \$ & 537 & \$ & 410 \\ \$ & 233 & \$ & 251 & \$ & 429 & \$ & 293 & \$ & 221 \\ \$ & 1,643 & \$ & 1,040 & \$ & 466 & \$ & 297 & \$ & 237 \\ \$ & 4,268 & \$ & 2,993 & \$ & 2,148 & \$ & 1,594 & \$ & 1,141 \\ \$ & 1,293 & \$ & 806 & \$ & 972 & \$ & 652 & \$ & 471\end{array}$

$\begin{array}{ccccc}7 & 13 & 31 & 39 & 33 \\ 36 & 37 & 42 & 56 & 52 \\ 51 & 54 & 33 & 37 & 35 \\ -8 & -4 & 40 & 58 & 50 \\ 22 \% & 17 \% & 13 \% & 9 \% & -3 \% \\ 73 \% & 64 \% & 28 \% & 23 \% & 8 \%\end{array}$

Table 7. Fiscal Year 1994-1998.

\section{CONCLUSION}

The purpose of this research was to explore the relationship of working capital management and profitability of the company. Working capital was presented and its elements were explored. Cash conversion cycle is the index that measures efficiency of working capital management. Cash conversion cycle decrease directionally may lead to a better position of working capital management. The low figure of this index is desirable and this study as many others show its negative correlation with company profitability.

Decrease of cash conversion cycle days may be an outcome of one three following elements: decrease of days that cash is tied up in inventory and accounts receivable and delaying of due dates of accounts payable. Each one of these activities may result in positive balance that can be employed in development financing.

This study also analyzes the connection between cash conversion cycle and supply chain management, as cash conversion cycle serves as a bridge between internal relations within the company and external relations. This index is relevant since it connects companies activities with suppliers, production process and customer relationships. 
The key items for further research are two major changes in Dell's business structure and their effect on working capital management. The first change is related to inventory management model in which Dell transitions from build to order model to combined model in which the company will hold higher levels of finished goods inventory. The second one is the fact that in 2013 Dell has become a privately held company.

\title{
UPRAVLJANJE OBRTNIM KAPITALOM U DELL INC
}

\author{
Kolar Nada
}

Sažetak: Predmet ovog istraživanja jeste odnos upravljanja obrtnim kapitalom i poslovanja preduzeća sa posebnim osvrtom na obrtni kapital i neto novčani tok u okviru kompanije Dell Inc. U literaturi operacionalnog finansijskog menadžmenta u poslednjem veku kao centralna tema preovladava pitanje kako poboljšati operativni učinak i smanjiti ciklus neto novčanog toka. Postoji sirroka literatura iz oblasti korporativnih finansija koja se specificno bavi neto novčanim tokom i vezuje ovaj indeks za profitabilnost, medutim nema mnogo studija koje se u analizi osvrću na lanac snabdevanja. Naučni cilj ovog istraživanja jeste deskripcija elemenata odnosa upravljanja obrtnim kapitalom i poslovanja kompanije izperspektive upravljanja lancem snabdevanja.

Ključne reči: upravljanje obrtnim kapitalom / obrt zaliha / lanac snabdevanja I ciklus konverzije gotovine

\section{LITERATURE}

1. Barr,S. (1998). Performance Measurement \& Risk management At Dell Computer Corp., speed and balance are the secret weapons to creating value, $C F O$ Magazine, http://www.cfo.com/printable/article.cfm/2990099?f=options.

2. Brealey, R. A., Myers, S. C., Marcus, A. J. (2012). Fundamentals of Corporate Finance.

3. Croxton, K. L., Lambert, D. M., García-Dastugue, S. J., Rogers, D. (2002). The Demand Management Process, The International Journal of Logistics Management, 13 (2), 51-66.

4. Deloof, M. (2003). Does Working Capital Management Affect Profitability of Belgian Firms? Journal of Business Finance \& Accounting. 
5. Demand Forecasting, http://www.myoops.org/cocw/mit/NR/rdonlyres/ Engineering-Systems-Division/ESD-260JFall2003/08F26A35-E6984FC6-8AC6-1B7445F1CE04/0/12_3demfcastpmas.pdf.

6. EoQ model Springer, www.springer.com/978-0-387-24492-1.

7. Fisher, L. M. (1998). Inside Dell Computer Corporation: Managing Working Capital, http://www.strategy-business.com/article/9571.

8. Gleissner, H., Femerling, J. C. (2013). Logistics.

9. Goldsby, T., Martichenko, R. (2005). Lean Six Sigma Logistics: Strategic Development to Operational Success.

10. Hutchinson, P. D., Farris II, T. M., Anders, S. B. (2007). Cash-to-Cash Analysis and Management. Useful Performance Measures for Improving Profitability, http://www.nysscpa.org/cpajournal/2007/807/essentials/p42. htm.

11. Inventory turnover, http://webuser.bus.umich.edu/dwwright/SamplePages_files/Inventory\%20Turnover.pdf.

12. Jordan, R. W. (2003). Fundamentals of Corporate Finance.

13. Kannan, V. R, Keah Choon, T. (2005). Just in time, Total quality management, and Supply Chain Management. Understanding their linkages and impact on business performance, http://www.deepdyve.com/lp/elsevier/ just-in-time-total-quality-management-and-supply-chain-managementaGZ4p4Kk50/2.

14. King, P. (2011). Crack the code: Understanding safety stock and mastering its equations.

15. Kumar, A.V. (2001). Working Capital Management.

16. Kumar, S. (2005). An Exploratory Analysis of Competing Supply Chains in the Personal Computer Industry.

17. Mentzer, J. T. (2001). Defining Supply Chain Management Journal of Business Logistics.

18. Mentzer, J. T., Moon, M. A., Estampe, D., Morgolis, G. (2007). Demand Management.

19. Roseman, A. (2009). How To Optimize Inventory Turnover Rates. Keep Cash In The Bank And Reduce Missed Sales Opportunities With This Formula.

20. Sagner, J. (2010). Essentials of Working Capital Management.

21. Simchi Levi, D. (2000). Designing and Managing Supply Chain.

22. Veselinović, B., Vunjak, N. (2014). Poslovne finansije - teorija i praksa (drugo izdanje), Fakultet za ekonomiju i inženjerski mendžment, Novi Sad

23. Dell financial data that was used in this research was downloaded from: http://www.dell.com/learn/us/en/uscorp1/about-dell-investor. 